\title{
PENGEMBANGAN MEDIA PEMBELAJARAN BERBASIS MULTIMEDIA INTERAKTIF DENGAN PENDEKATAN SAINTIFIK PADA TEMA INDAHNYA KERAGAMAN DI NEGERIKU DI KELAS IV SD NEGERI 101969 TANJUNG PURBA
}

\author{
Lala Jelita Ananda, Nuraini \\ Surel: nuraini14976@gmail.com
}

\begin{abstract}
The purpose of the study was to determine the validity of the learning media, to find out the practicality of learning media developed on the theme of the beauty of diversity in my country. The type of research is development research $(R \& D)$ using a 4-D model consisting of four stages, namely Define, Design, Develop, and Disseminate. The subjects in this study were grade IV students of Tanjung Purba State Elementary School 101969 which numbered 23 students. The data collection technique in this study was to use the results of assessments on aspects of media feasibility and material feasibility, the results of teacher responses to the practicality of learning media and the results of student responses after product trials. Based on the results of the study obtained the results of the feasibility of learning media by media experts by $92 \%$, the results of material feasibility by material experts I obtained a percentage of $83 \%$, the results of material feasibility by material experts II obtained a percentage of $86 \%$ and the results of assessment of teacher responses to the practicality $92 \%$. From learning activities and data analysis research conducted by researchers, it can be concluded that the Development of Learning Media Based on Interactive Multimedia with a Scientific Approach in the Theme of Beautiful Diversity in My Country is valid and practical for use in the teaching-learning process and in accordance with the characteristics of students in class IV Tanjung Purba State Elementary School 101969.
\end{abstract}

Keywords: Learning Media, Interactive Multimedia, Scientific Approach.

\begin{abstract}
ABSTRAK
Tujuan dari penelitian adalah untuk mengetahui validitas media pembelajaran, mengetahui kepraktisan media pembelajaran yang dikembangkan pada tema indahnya keragaman di negeriku.Adapun jenis penelitian merupakan penelitian pengembangan $(R \& D)$ dengan menggunakan model 4-D yang terdiri dari empat tahap yaitu Define, Design, Develop, dan Disseminate. Subjek dalam penelitian ini adalah siswa kelas IV SD Negeri 101969 Tanjung Purba yang berjumlah 23 siswa. Teknik pengumpulan data dalam penelitian ini adalah menggunakan hasil penilaian pada aspek kelayakan media dan kelayakan materi, hasil tanggapan guru tentang kepraktisan media pembelajaran dan hasil tanggapan siswa setelah ujicoba produk. hasil penelitian diperoleh hasil kelayakan media pembelajaran oleh ahli media sebesar 92\%, hasil kelayakan materi oleh ahli materi I diperoleh persentase sebesar 83\%, hasil kelayakan materi oleh ahli materi II memperoleh persentase sebesar $86 \%$ dan hasil penilaian tanggapan guru terhadap kepraktisan media pembelajaran sebesar $92 \%$. Dari kegiatan pembelajaran dan analisis data penelitian yang dilakukan oleh peneliti, maka dapat disimpulkan adalah bahwa Pengembangan Media Pembelajaran Berbasis Multimedia Interaktif.
\end{abstract}

Kata Kunci: Media Pembelajaran,Multimedia Interaktif, Pendekatan Saintifik. 


\section{PENDAHULUAN}

Pendidikan merupakan suatu aspek kehidupan yang sangat mendasar dan memiliki peran penting bagi pembangunan bangsa. Salah satu yang menentukan maju mundurnya suatu bangsa adalah dilihat dari mutu pendidikannya, oleh sebab itu pembangunan sektor pendidikan harus menjadi prioritas. Kerena melalui pendidikan manusia akan tumbuh dan berkembang sebagai pribadi yang utuh.

Undang-undang Sistem

Pendidikan Nasional No.20 Tahun 2003 menjelaskan bahwa pembelajaran diartikan sebagai proses interaksi peserta didik dengan pendidik dan sumber belajar pada suatu lingkungan belajar. Menurut pengertian ini, pembelajaran merupakan bantuan yang diberikan pendidik kepada peserta didik agar terjadi proses mendapatkan ilmu pengetahuan, penguasaan terhadap apa yang disampaikan pendidik. Dengan kata lain, pembelajaran merupakan proses untuk membantu peserta didik agar dapat belajar dengan baik.

Lewis (2008:6) menuliskan bahwa pembelajaran yang ideal merupakan pembelajaran yang efektif. Interaksi yang baik antara guru dan peserta didik sesuatu yang harus terjadi, interaksi yang dimaksud adalah hubungan timbal balik antara guru dan peserta didik, peserta didik dengan guru dan peserta didik dengan peserta didik lainnya. Arsyad (2007:15) mengatakan bahwa pemilihan metode mengajar dan media pembelajaran yang tepat adalah hal penting yang harus ada dalam suatu proses belajar mengajar.

Dunia pendidikan tidak lepas dari era globalisasi teknologi yang berkembang pada masa sekarang. Pendidikan sendiri sangat merasakan kebutuhan terhadap pentingnya dalam menyampaikan materi dengan media teknologi komputer saat ini. Kemampuan mendidik dalam mengembangkan media pembelajaran merupakan salah satu faktor penentu keberhasilan peserta didik dalam mencapai kompetensi yang diharapkan. Dengan penggunaan media dalam proses pembelajaran dapat membangkitkan keinginan dan minat yang baru, membangkitkan motivasi dan rangsangan kegiatan belajar dan bahkan membawa pengaruh psikologi pada siswa. Dengan kata lain penggunaan media dalam pembelajaran akan sangat membantu keefektifan proses pembelajaran dan penyampaian pesan serta isi pelajaran.

Media merupakan suatu unit pembelajaran lengkap yang berdiri sendiri dan terdiri atas suatu rangkaian kegiatan belajar yang disusun untuk membantu isi belajar mencapai sejumlah tujuan yang telah dirumuskan secara khusus dan jelas. Media pembelajaran merupakan solusi yang tepat digunakan untuk mewujudkan pembelajaran yang menyenangkan bagi siswa, karena media dapat membangkitkan motivasi belajar siswa. Disamping 
membangkitkan motivasi dan minat siswa, media pembelajaran juga dapat membantu siswa meningkatkan pemahaman dan menyajikan data dengan menarik. Dengan demikian, akan terjadi interaksi edukatif antara guru dan siswa, sehingga terdapat perubahan dalam diri siswa baik pemahaman dan keterampilan atau sikap.

Salah satu lingkungan belajar
yang sangat berperan dalam memudahkan penguasaan peserta didik terhadap kompetensi adalah penerapan teknologi dalam penggunaan media pembelajaran. Media pembelajaran sebenarnya merupakan alat bantu yang dapat digunakan oleh pendidik dalam membantu tugas kependidikannya. Media pembelajaran juga dapat memudahkan pemahaman peserta didik terhadap kompetensi yang harus dikuasai terhadap materi yang harus dipelajari, yang pada akhirnya diharapkan dapat mempertinggi hasil belajar. Program untuk pembuatan media pembelajaran berbasis komputer yang kreatif dan inovatif kini sudah banyak tersedia. Salah satunya ialah program Microsoft Office PowerPoint. Microsoft Office PowerPoint adalah software yang digunakan sebagai media alat bantu presentasi, biasanya digunakan untuk menjelaskan suatu hal yang dirangkum dan dikemas dalam slide power point.

Berdasarkan hasil observasi yang dilakukan pada siswa kelas IV SD Negeri 101969 Tanjung Purba ditemukan suasana kelas yang tidak kondusif disaat kegiatan belajar mengajar berlangsung, siswa asik dengan kesibukan mereka masingmasing. Ditemukan beberapa anak yang mengantuk di dalam kelas saat proses pembelajaran. Berdasarkan hasil wawancara dengan guru kelas IV SD Negeri 101969 Tanjung Purba, diperoleh informasi bahwa beberapa faktor yang menjadi permasalahan dalam proses pembelajaran diantaranya adalah penggunaan metode pembelajaran yang kurang bervariasi menyebabkan kurangnya keaktifan siswa dalam belajar. Guru belum menguasai model atau metode pembelajaran sehingga guru merasa kesulitan dalam menentukan model atau metode pembelajaran, sehingga lebih banyak menggunakan metode ceramah. Selain itu, guru kurang inovatif dalam mengembangkan media pembelajaran khususnya pada tema indahnya keragaman di negeriku. Guru cenderung tidak memiliki banyak waktu dan kesulitan menjabarkan materi pelajaran sehingga siswa kesulitan dalam memahami materi yang disampaikan oleh guru. Ketika guru meminta siswa untuk menyimak buku, banyak siswa yang kurang memperhatikan terlihat dari reaksi ketika diminta untuk menjawab pertanyaan, siswa tidak merespon. Guru menyatakan tidak pernah menggunakan media lain selain media gambar ataupun media berbasis komputer dikarenakan kurangnya fasilitas dan keterampilan guru dalam menggunakannya. Dengan adanya 
media pembelajaran multimedia interaktif untuk pembelajaran tematik adalah media yang perlu dikembangkan di SD Negeri 101969 Tanjung Purba. Dengan adanya media pembelajaran multimedia interaktif ini siswa diharapkan lebih termotivasi dan bisa lebih aktif dalam belajar serta dapat meningkatkan hasil belajar siswa.

\section{METODE PENELITIAN}

Penelitian ini merupakan jenis penelitian pengembangan (Research \& Development). Menurut Sugiyono (2016:279), "metode penelitian pengembangan adalah metode penelitian yang digunakan untuk menghasilkan produk tertentu, dan menguji keefektifan tersebut". Penelitian ini menggunakan model pengembangan 4-D.

Penelitian ini dilakukan di SD Negeri 101969 Tanjung Purba yang terletak di Desa Paya Kuda Kecamatan Galang Kabupaten Deli serdang pada siswa kelas IV. Subjek pada penelitian ini adalah siswa kelas IV di SD Negeri 101969 Tanjung Purba yang berjumlah 23 siswa, terdiri dari 13 orang siswa Perempuan dan 10 orang siswa lakilaki.

Pengumpulan data yang digunakan dalam penelitian ini adalah dengan menggunakan lembar angket.

\section{HASIL PENELITIAN DAN PEMBAHASAN}

Untuk menghasilkan tujuan tersebut, terlebih dahulu dilakukan penelitian pengembangan

menggunakan Model 4-D dari Thiagarajan yang telah dimodifikasi. Hasil multimedia interaktif pada tema Indahnya Keragaman Di Negeriku.

Tahap pengembangan media pembelajaran ini menggunakan model pengembangan 4-D (four $D$ Model) yang dikemukakan Thiagarajan, Semmel dan semmel. Model ini terdiri dari empat tahap. Tahap pertama dimulai dari tahap pendefenisian (define), tahap kedua perancangan (design), tahap ketiga pengembangan (develop) dan tahap terakhir penyebaran (disseminate).

Berdasarkan hasil analisis terhadap kurikulum yang digunakan dalam pembelajaran tematik di kelas IV SD Negeri 101969 khususnya pada tema 7 Indahnya Keragaman Di Negeriku dan Subtema 1 Keragaman Suku Bangsa dan Agama di Negeriku terdapat 2 pembelajaran yang berkaitan dengan materi IPA.

Pada tahap analisis kebutuhan media, kegiatan yang dilakukan peneliti adalah menganalisis media pembelajaran yang digunakan guru dalam proses pembelajaran di SD Negeri 101969 Tanjung Purba. Media pembelajaran yang digunakan adalah gambar-gambar sederhana dari karton. Dari analisis yang dilakukan tidak terdapat media pembelejaran berbasis multimedia interaktif.

Pada tahap analisis materi, materi pelajaran yang digunakan dalam penelitian ini adalah tema 7 Indahnya Keragaman di Negeriku 
Subtema 1 Keragaman Suku Bangsa Dan Agama Di Negeriku untuk kelas IV dengan mengacu pada kurikulum 2013. Analisis materi ini ditujukan untuk ditampilkan pada media pembelajaran yang akan dikembangkan.

Setelah melakukan analisis terhadap media yang akan dikembangkan berdasarkan data observasi. Adapun tahap-tahap pengembangan media berbasis multimedia interaktif ini adalah sebagai berikut: 1) Perumusan Pengembangan Media Pembelajaran; 2) Pengembangan Media Pembelajaran Berbasis Multimedia Interaktif.

Tahap pendefenisian dan perancangan menghasilkan rancangan awal sebuah media pembelajaran yang disebut dengan draft 1. Fase pertama pada tahap pengembangan adalah melakukan validasi draft 1 kepada para ahli dan kemudian dilakukan ujicoba lapangan.

Validator yang dipilih dalam penelitian ini terdiri dari tiga orang dosen di UNIMED.Selanjutnya validator dibagi ke dalam dua bagian, dimana bagian pertama sebagai ahli media pembelajaran, bagian kedua sebagai ahli materi pelajaran.

Validator untuk ahli media pembelajaran yang dilakukan oleh Ibu Dra. Eva Betty Simanjuntak, M.Pd yang ahli dalam bidang ilmu teknologi pendidikan. Tujuan dari validasi ahli media adalah agar produk yang dihasilkan tidak lari dari konsep pembelajaran di sekolah. Berdasarkan validasi media pertama di peroleh rata-rata skor $60 \%$ dimana masih dalam kategori cukup valid dan didapatkan catatan-catatan mengenai kekurangan yang harus direvisi dari ahli media pada tahap validasi ini antara lain: 1) huruf yang digunakan dalam materi harus berukuran besar agar siswa dapat membaca dengan jelas, 2) background disesuaikan dengan materi pelajaran, 3) video belum bisa tampil. Dan validasi kedua di peroleh rara-rata skor presentase $92 \%$.

Validasi materi dilakukan oleh dua dosen ahli materi yaitu bapak Faisal, S.Pd., M.Pd. dan Bapak Fahrur Rozi, S.Pd., M.Pd. tujuan dari dilakukannya validasi ahli materi adalah untuk mengetahui ketepatan dan kesesuaian aspek kandungan materi dari produk yang peneliti kembangkan apakah sudah sesuai dengan kebutuhan pembelajaran yang digunakan. Dari hasil validasi yang dilakukan oleh ahli materi pembelajaran pertama diperoleh hasil validasi sebesar $68 \%$ dan dinyatakan cukup valid serta perlu dilakukan revisi kembali. Diantaranya perlu menambahkan: 1) Tujuan pembelajaran, 2) Perbaiki kegiatan ayo bernyanyi, 3) Tambahkan perintah pada kegiatan ayo berdiskusi, 4) Perbaiki soal evaluasi, 5) Tambahkan backsound pada setiap slide agar lebih menarik.

Setelah dilakukannya revisi sesuai dengan masukan yang diberikan oleh validator ahli materi maka pada pertemuan kedua materi 
tersebut dinyatakan sangat valid dimana persentase skor mencapai $83 \%$.

Validasi kedua yang dilakukan oleh ahli materi Bapak Faisal, S.Pd., M.Pd.dan diperoleh hasil validasi sebesar $77 \%$ dan dinyatakan cukup valid serta perlu dilakukan revisi kembali. Diantaranya perlu menambahkan: 1) Perbaiki peletakan tanda baca, 2) Perbaiki penggunaan bahasa, 3) Perbaiki peletakan gambar pada media agar tidak monoton, 4) Sesuaikan penomoran indikator dengan kompetensi dasar.

Setelah dilakukannya revisi sesuai dengan masukan yang diberikan oleh validator ahli materi maka pada pertemuan kedua materi tersebut dinyatakan sangat valid dimana persentase skor mencapai $86 \%$.

Hasil valiidasi media pembelajaran dapat dilihat pada tabel berikut:

Tabel 1. Hasil Validasi Tim Ahli

\begin{tabular}{|c|c|c|c|c|c|}
\hline No. & Validator & $\begin{array}{c}\text { Hasil } \\
\text { Validasi } \\
\text { I }\end{array}$ & $\begin{array}{c}\text { Hasil } \\
\text { Validasi } \\
\text { II }\end{array}$ & $\begin{array}{c}\text { Rata- } \\
\text { rata } \\
\text { Total }\end{array}$ & Kriteria \\
\cline { 1 - 4 } 1. & $\begin{array}{c}\text { Ahli } \\
\text { Media }\end{array}$ & $60 \%$ & $92 \%$ & \multirow{2}{*}{$87 \%$} & $\begin{array}{c}\text { Sangat } \\
\text { Valid }\end{array}$ \\
\cline { 1 - 4 } 2. & $\begin{array}{c}\text { Ahli } \\
\text { Materi I }\end{array}$ & $68 \%$ & $83 \%$ & $86 \%$ & \\
\hline 3. & $\begin{array}{c}\text { Ahli } \\
\text { Materi II }\end{array}$ & $77 \%$ & $87 \%$ & \\
\hline
\end{tabular}

Setelah media pembelajaran yang dikembangkan oleh peneliti telah memenuhi kriteria kevalidan menurut ahli, maka selanjutnya media pembelajaran ini diujicobakan di lapangan yaitu pada siswa kelas IV SD Negeri 101969 Tanjung Purba.Data yang diperoleh dari hasil uji coba untuk mengukur tingkat kepraktisan media berupa angket yang diisi sendiri oleh guru kelas IV dan hasil tanggapan siswa mengenai media pembelajaran yang peneliti kembangkan. Setelah dilakukannya uji coba peneliti memberikan lembar kepraktisan kepada guru kelas IV untuk mengetahui tanggapan guru tentang media pembelajaran. Peneliti melakukan penyebaran lembar pertanyaan kepada siswa yang diisi oleh masing-masing ketua kelompok adapun hasil tanggapan guru tentang kepraktisan media pembelajaran yang telah peneliti kembangkan.

Setelah dilakukannya uji coba pada media pembelajaran sehingga memperoleh hasil kepraktisan media dari guru pada pertemuan pertama maka perlu perbaikan media berupa penambahan animasi atau gambar yang lebih nyata serta menarik dan perbaikan ukuran sistematika penulisan agar lebih terlihat dengan jelas.

Setelah dilakukannya revisi sesuai masukan yang diberikan oleh 
guru maka pada pertemuan kedua media tersebut dinyatakan sangat valid dimana memperoleh presentase skor sebesar 92\%. Dan diketahui respon guru terhadap media yang dikembangkan dengan pencapaian persentase $92,85 \%$ yang termasuk dalam kategori sangat positif. Sehingga dilihat dari respon guru terhadap media, layak untuk digunakan sebagai media pembelajaran.

Setelah dilakukan validasi media oleh beberapa validator maka selanjutnya peneliti melakukan wawancara. Setelah dilakukannya wawancara kepada siswa maka diperoleh hasil tanggapan siswa yaitu siswa merasa senang dengan media pembelajaran yang peneliti kembangkan karena siswa dapat mengetahui keberagaman yang ada di Indonesia, dengan adanya media pembelajaran siswa merasa sangat senang dan lebih mengerti karena dapat memotivasi siswa, siswa menyatakan bahwa media pembelajaran yang peneliti kembangkan cocok untuk digunakan dalam kegiatan belajar mengajar, siswa menyimpulkan bahwa kegiatan yang ada pada media pembelajaran tidak ada yang sulit karena perintah di dalam media sudah jelas dan siswa menyatakan media pembelajaran yang peneliti kembangkan sangat mendukung dan membantu untuk proses belajar mengajar.

\section{Pembahasan}

Hasil dari pengembangan media pembelajaran ini ialah terciptanya sebuah media pembelajaran berbasis pendekatan saintifik pada kelas IV semester II. Pengembangan media pembelajaran ini telah melalui proses perbaikanperbaikan tulisan yang mencakup isi, penyajian dan bahasa terhadap kelayakan media pembelajaran, kevalidan media pembelajaran, serta kepraktisan media pembelajaran. Adapun validator-validator untuk menilai kelayakan media pembelajaran ini yaitu Ibu Dra. Eva Betty Simanjuntak, M.Pd, Bapak Fahrur Rozi, S.Pd, M.Pd, dan Bapak Faisal, S.Pd, M.Pd, serta penilai kepraktisan media pembelajarn oleh Ibu Arista Purba, S.Pd. maka diperoleh hasil penilaian yang baik dan sangat layak untuk digunakan untuk proses belajar mengajar.

Kelayakan media pembelajaran tematik berbasis multimedia interaktif mengacu kepada kualitas produk. Suatu produk dikatakan layak untuk digunakan apabila produk tersebut mempunyai dua kriteria kualitas produk yaitu kevalidan dan kepraktisan.

Tahapan yang harus dilalui sebelum uji coba produk ke lapangan adalah melakukan validasi produk kepada validator tim ahli. Validator tersebut terdiri dari ahli media pembelajaran dan ahli materi pembelajaran. Produk layak diuji cobakan ke lapangan apabila tim ahli telah memvalidasi produk dengan kategori valid tanpa revisi. Ahli media pembelajaran pada validasi ke I yang dilakukan oleh Ibu Dra. Eva 
Betty Simanjuntak, M.Pd mengklasifikasikan media pembelajaran dengan kategori valid, tetapi revisi beberapa aspek. Revisi tersebut antara lain: 1) huruf yang digunakan dalam materi harus berukuran besar, agar siswa dapat membaca dengan jelas, 2) background sesuaikan dengan materi pelajaran, 3) video belum bisa tampil. Hasil validasi produk pada pertemuan ke II, validator memberikan skor maksimal pada setiap indikator penilaian karena menurut validator revisi telah dilakukan dengan baik dan media pembelajaran diklasifikasikan sangat valid. Ahli materi pertama pada validasi ke I yang dilakukan oleh Bapak Fahrur Rozi, S.Pd, M.Pd mengklasifikasikan media pembelajaran dengan kategori valid dengan revisi. Revisi dari ahli materi antara lain adalah 1) Tujuan pembelajaran, 2) Perbaiki kegiatan ayo bernyanyi, 3) Tambahkan perintah pada kegiatan ayo berdiskusi, 4) Perbaiki soal evaluasi, 5) Tambahkan backsound pada setiap slide agar lebih menarik. Validasi pada pertemuan II semua hasil revisi ditinjau oleh validator. Hasil validasi pada pertemuan II adalah media diklasifikasikan valid tanpa ada revisi. Ahli materi kedua pada validasi ke I yang dilakukan oleh Bapak Faisal, S.Pd, M.Pd mengklasifikasikan media pembelajaran dengan kategori valid dengan revisi. Revisi dari ahli materi antara lain adalah: 1) Perbaiki peletakan tanda baca, 2) Perbaiki penggunaan bahasa, 3) Perbaiki peletakan gambar pada media agar tidak monoton, 4) Sesuaikan penomoran indikator dengan kompetensi dasar. Hasil validasi pertemuan ke II semua hasil revisi media pembelajaran ditinjau oleh validator kemudian validator mengklasifikasikan media pembelajaran dengan kategori valid tanpa ada revisi.

Karakteristik kedua dari produk berkualitas tinggi adalah praktis. Kepraktisan media pembelajaran diukur melalui data tanggapan siswa yang diperoleh dari masing-masing ketua kelompok terhadap media pembelajaran dan angket respon guru yang diberikan setelah menggunakan media pembelajaran berbasis multimedia interaktif dalam proses pembelajaran. Hasil analisis yang diperoleh dari tanggapan masingmasing ketua kelompok pada uji coba I adalah bahwa media yang peneliti kembangkan sudah ditegorikan praktis, tetapi masih terdapat kekurangan pada aspek yang ada pada media yang harus diperbaiki agar media pembelajaran tersebut dapat dinyatakan praktis dan layak digunakan pada proses belajar mengajar. Kekurangan tersebut adalah pada bagian background yang ditampilkan kurang berwarna dan ukuran tulisan belum konsisten. Peneliti melakukan uji coba ke II pada siswa yang sama setelah melakukan revisi dari kekur.angan pada aspek yang ada pada media pembelajaran. Hasil tanggapan dari 
masing-masing ketua kelompok pada uji coba ke II dapat disimpulkan bahwa media pembelajaran tersebut dikategorikan praktis oleh seluruh siswa kelas IV SD Negeri 101969 Tanjung purba.

\section{SIMPULAN}

Berdasarkan hasil analisis dan pembahasan dalam penelitian ini, dikemukakan beberapa kesimpulan sebagai berikut:

a. Media pembelajaran berbasis multimedia interaktif yang dikembangkan ini telah divalidasi oleh validator ahli media yaitu Ibu Dra. Eva Betty Simanjuntak, M.Pd dengan memperoleh persentase kelayakan sebesar 92\% maka media pembelajaran dikategorikan sangat valid dan praktis digunakan dalam proses belajar mengajar.

b. Media pembelajaran berbasis multimedia interaktif yang dikembangkan ini telah divalidasi oleh validator ahli materi I yaitu Bapak Fahrur Rozi, S.Pd, M.Pd dengan memperoleh hasil validasi materi sebesar $83 \%$. Dan validator ahli materi II oleh Bapak Faisal, S.Pd., M.Pd memperoleh hasil validasi sebesar $86 \%$. dari hasil yang telah diperoleh dari kedua validator ahli materi dapat dinyatakan bahwa media pembelajaran sangat valid dan layak digunakan untuk kegiatan belajar mengajar.

c. Media pembelajaran berbasis multimedia interaktif yang dikembangkan telah memenuhi kriteria kepraktisan karena dapat digunakan dengan baik oleh pengguna yaitu dan siswa yang ditunjukkan melalui hasil skor respon guru yaitu sebesar $92,85 \%$.

\section{DAFTAR RUJUKAN}

Arsyad, Azhar. 2011. Media Pembelajaran. Jakarta: Raja Grafindo Persada.

Lewis, G. 2008. Pembelajaran aktif meningkatkan keasyikan kegiatan di kelas. Jakarta: PT Indeks.

Sugiyono. 2016. Metode Penelitian Pendidikan Kuantitatif Kualitatif dan R\&D. Bandung: Alfabeta. 